\title{
Synergistic apoptotic effect of Arabinoxylan rice bran (MGN-3/Biobran) and Curcumin (Turmeric) on human multiple myeloma cell line U266 in vitro
}

\author{
M. GHONEUM ${ }^{1}$, S. GOLLAPUDI ${ }^{2}$ \\ ${ }^{1}$ Department of Otolaryngology, Charles Drew University of Medicine and Science, 1621E. 120th Street, Los Angeles, CA 90059 USA, e-mail: \\ mghoneum@ucla.edu; ${ }^{2}$ University of California at Irvine, Division of Basic and Clinical Immunology, Irvine, CA 92697
}

\author{
Received July 30, 2010
}

\begin{abstract}
The present study was carried out to investigate the synergistic apoptotic potential of arabinoxylan rice bran (MGN3/Biobran) and curcumin (turmeric) on human multiple myeloma (MM) cell line U266, in vitro. U266 cells were cultured with MGN-3 (50 or $100 \mu \mathrm{g} / \mathrm{ml})$ and curcumin $(2.5-10 \mu \mathrm{M})$ for 3 days. The effects of MGN-3 and curcumin on the growth and survival of the U266 cells were determined by trypan blue, MTT assay, flow cytometry analysis of cancer cell cycle, and apoptosis. Expression of proapoptotic Bax, and antiapoptotic Bcl2 was determined by Western blot analysis. Treatment with MGN-3 alone or curcumin alone caused a dose-dependent inhibition in the proliferation of U266 cells. However, a synergistic effect was noticed post-treatment with both agents that maximized at $100 \mu \mathrm{g} / \mathrm{ml} \mathrm{MGN-3}$ plus $10 \mu \mathrm{M}$ curcumin. This synergy was characterized by an $87 \%$ decrease in cell number and a 2.6 fold increase in the percentage of apoptotic U266 cells. Cell cycle analysis showed a 53\% decrease in the percentage of cells in the G0-G1 phase treated with MGN-3 and curcumin (from $36 \%$ to $17 \%$ ). Analysis of the expression of the pro and antiapoptotic molecules Bax and Bcl-2 revealed synergistic effects of these agents, as the expression of Bcl-2 was decreased and Bax was increased. This resulted in a cellular microenvironment favorable for apoptosis. We conclude that MGN-3 and curcumin synergize in the induction of U266 cell apoptosis. This data may establish the foundation for in vivo studies that could have therapeutic implications.
\end{abstract}

Key words: U266, MGN-3, curcumin, cancer cell survival, synergistic effect

Multiple myeloma (MM) is a B-cell malignancy characterized by the latent accumulation in bone marrow of secretory plasma cells with a low proliferative index and an extended life span [1]. MM accounts for more than $10 \%$ of all hematologic cancers. Various agents used for the treatment of myeloma include combinations of vincristine, Bis-2-chloroethylnitrosourea (BCNU), melphalan, cyclophosphamide, adriamycin, and prednisone or dexamethasone [2]. Usually, patients younger than 65 years are treated with high-dose melphalan with autologous stem-cell support, and older patients who cannot tolerate such intensive treatment receive standard-dose oral melphalan and prednisone. Despite these treatments, this malignancy remains incurable, with a complete remission rate of only $5 \%$ and a median survival of 30 to 36 months $[3,4]$. It is therefore of particular interest to explore new therapeutic approaches for fighting MM.

Arabinoxylan rice bran (MGN-3) and curcumin are natural products that have been demonstrated to be promising anti cancer agents in animal models [5-9]. MGN-3 is obtained by reacting rice bran hemicellulose with multiple carbohydrate hydrolyzing enzymes from shiitake mushrooms. The main chemical structure of MGN-3 is arabinoxylan, with a xylose in its main chain and an arabinose polymer in its side chain [10]. MGN-3 has been demonstrated to be a potent activator of natural killer (NK) cells $[11,12]$. Previously, we presented evidence for the role of MGN-3 as a sensitizer of human leukemic HUT78 cells to anti-CD95 antibody-induced apoptosis [13]. Turmeric (curcuma longa), which is widely used as a spice and coloring agent in several foods, has recently been shown to possess anticancer activity $[5-6,8]$. The active ingredient of curcumin is diferuloylmethane. In this study, we examined the ability of MGN-3 to synergize with curcumin to induce apoptosis of U266 cells, a human MM cell line, and examined the possible mechanism(s) underlying this effect.

\section{Materials and methods}

Tumor cell line and culture condition. The human multiple myeloma cell line, U266, is a plasmacytoma of $\mathrm{B}$-cell origin and they were obtained from the American 
Type Culture Collection (ATCC; Rockville, MD). Tumor cells were maintained in our laboratory in a complete medium (CM) that consisted of RPMI-1640 (Irvine Scientific, Irvine) supplemented with $10 \%$ fetal calf serum (FCS, In vitrogen, Carlsbad, CA ), $2 \mathrm{mM}$ glutamine, and $100 \mathrm{mg} / \mathrm{ml}$ streptomycin and $100 \mathrm{U} / \mathrm{mol}$ penicillin (Sigma Chemicals, St. Louis, MO)

MGN-3. MGN-3 is a denatured hemicellulose obtained by reacting rice bran hemicellulose with multiple carbohydrate hydrolyzing enzymes from Shiitake mushrooms. MGN-3 was dissolved in CM at a concentration of $30 \mathrm{mg} / \mathrm{ml}$. MGN-3 was provided by Daiwa Pharmaceutical Co. Ltd., Tokyo, Japan.

Curcumin (turmeric). Curcumin was purchased from Sigma-Aldrich Chemicals (St. Louis, MO). Curcumin was prepared as a $20-\mathrm{mM}$ solution in dimethyl sulfoxide and then further diluted in CM.

Cell growth and survival assays. U266 cells ( $1 \times 10^{4} /$ well) were seeded in 96-well plates and cultured in triplicate in the presence or absence of various concentrations of curcumin $(2.5,5$ and $10 \mu \mathrm{M})$ and/or MGN-3 (50 and $100 \mu \mathrm{g} / \mathrm{ml})$. The final volume of medium in each well after addition of curcumin and/ or MGN-3 was $200 \mu \mathrm{l}$. Blank wells containing medium only and cells treated with DMSO $(0.05 \%)$ were used as additional controls. The plates were incubated at $37^{\circ} \mathrm{C}$ in humidified $5 \%$ $\mathrm{CO}_{2} .72$ hours after treatment, the antiproliferative effects of curcumin, MGN-3 and their combination against U266 cells were determined by standard trypan blue dye exclusion and MTT dye uptake methods as described earlier [14,15]. In this study, we terminated experiments 72 hours post-treatment based on previous work on MGN-3 and curcumin by ourselves and others [14,16-18].

Trypan blue dye exclusion method. Trypan blue was used to determine the U266 cell growth and survival after culturing with MGN-3 $(50$ and $100 \mu \mathrm{g} / \mathrm{ml})$ and curcumin $(2.5-10 \mu \mathrm{M})$ for 3 days. $100 \mu$ of trypan blue ( $0.4 \%$ solution) was added to an equal volume of treated and untreated cells. After five minutes following the addition of trypan blue, the percentages of viable (unstained) and non-viable (stained) cells were determined using a hemacytometer.

MTT assay. This assay is based on the reduction of tetrazolium salt MTT [3-(4,5-dimethylthiozol-3-yl)-2,5diphenyltetrazolium bromide; Sigma-Aldrich Chemicals, St. Louis, $\mathrm{MO}$ ] by a mitochondrial dehydrogenase in viable cells, resulting in a change from a colorless to a blue-colored formazan product that can be measured spectrometrically. The amount of formazan produced is proportional to the number of living cells. Briefly, U266 cells were treated with or without curcumin in the presence or absence of MGN-3 as described above. 72 hours post-treatment, MTT ( $50 \mu \mathrm{g} /$ well) was added to each well and the cultures were incubated for an additional $4 \mathrm{~h}$. The plates were then centrifuged and the medium carefully removed. The formazan crystals were solubilized with acidic alcohol, and the plates were read at $\lambda=590 \mathrm{~nm}$ using an ELISA plate reader (Molecular Devices, Menlo Park, CA). The following formula was used: Percentage cell viability $=(\mathrm{OD}$ of the experiment samples/OD of the control) $\times 100$, where OD is optical density.

Cell cycle analysis. Flow cytometry was used to determine the effect of MGN-3 $(50 \mu \mathrm{g} / \mathrm{ml})$, curcumin $(10 \mu \mathrm{M})$, and MGN-3 plus curcumin on the cell cycle and apoptosis. U266 cells that were treated with MGN-3 and/or curcumin for 72 hours, washed, and fixed with $70 \%$ ethanol. After incubation overnight at $-20^{\circ} \mathrm{C}$, cells were washed with PBS, then stained with propidium iodide (PI) and suspended in staining buffer $(10 \mu \mathrm{g} / \mathrm{mL}$ PI; $0.5 \%$ Tween-20; 0.1\% RNase in PBS). The cells were analyzed by means of a fluorescence-activated cell sorted (FACS) caliber flow cytometer (Becton Dickinson, San Jose, CA). Cells were gated to exclude cell debris, cell doublets, and cell clumps. The proportion of cells with hypodiplod DNA as well as cell cycle phases were analyzed by CellQuest and Modfit analysis programs.

Western blot analysis. The expression of Bax and $\mathrm{Bcl}-2$ was determined using Western blot analysis. The cells were cultured with MGN-3 $(50 \mu \mathrm{g} / \mathrm{ml})$, curcumin $(5 \mu \mathrm{M})$, and MGN-3 plus curcumin for 1 day. The cells were harvested, washed with cold PBS (10 mmol/L [pH 7.4]), and lysed with ice-cold lysis buffer $(50 \mathrm{mmol} / \mathrm{L}$ Tris- $\mathrm{HCl}, 150 \mathrm{mmol} / \mathrm{L} \mathrm{NaCl}, 1 \mathrm{mmol} / \mathrm{L}$ ethylene glycol tetraacetic acid [EGTA], $1 \mathrm{mmol} / \mathrm{L}$ EDTA, $20 \mathrm{mmol} / \mathrm{L} \mathrm{NaF}, 100 \mathrm{mmol} / \mathrm{L} \mathrm{Na}_{3} \mathrm{VO}_{4}, 1 \% \mathrm{NP} 40,1 \mathrm{mmol} /$ Lphenylmethylsulfonyl fluoride, $10 \mathrm{Ag} / \mathrm{mL}$ aprotinin, and $10 \mathrm{Ag} / \mathrm{mL}$ leupeptin [pH 7.4]) for 30 minutes and centrifuged at $14,000 . \mathrm{g}$ for 20 minutes at $4^{\circ} \mathrm{C}$ as detailed previously. The supernatant was collected and used immediately. The protein concentration was determined using a BCA protein assay kit (Pierce, Rockford, IL, USA) according to the manufacturer's protocol. Seventy-five $\mu \mathrm{g}$ of the cell lysate in lysis buffer were subjected to Western blot analysis by $4 \%-12 \%$ SDS polyacrylamide gel electrophoresis using 1:500 anti-Bax antibody or anti-Bcl-2 antibody (BD Biosciences, San Jose, CA, USA) as primary antibody. The washed polyvinylidene fluoride (PVDF) membranes were incubated with a 1:2000 dilution of monoclonal secondary antibodies. The immunoreactive bands were visualized by using an ECL Western Blotting Kit (Amersham, Buckinghamshire, UK). To verify equal protein loading and transfer, the blots were stripped and re-probed with $\beta$-actin using an anti-actin rabbit polyclonal antibody; thereafter the same protocol was followed as detailed above. The relative intensity of each protein band in a blot was measured by using the computerized software program OPTIMAS 6.2 (Media Cybernetics, Silver Spring, MD, USA) and the ratio of Bcl-2 to Bax was analyzed. The band intensities were determined using Quantity One software from Bio-Rad.

Statistical analysis. Statistical significance was determined by Student's $t$ test. Differences were considered significant at the $\mathrm{p}<0.05$ level.

\section{Results}

Effects of MGN-3 and curcumin on U266 cell survival. The effects of MGN-3 and curcumin treatments on the growth 


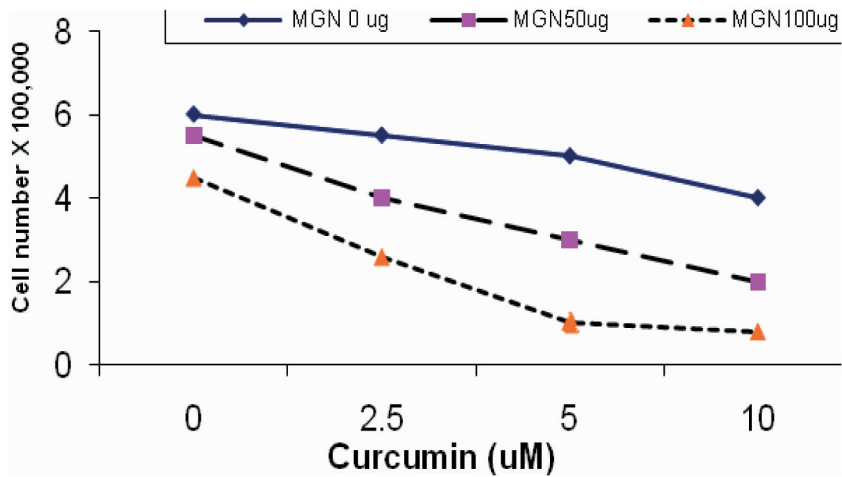

Figure 1. Synergistic effect of MGN-3 and curcumin on U266 cell growth via Trypan blue method. U266 cells were cultured with MGN-3 (50 and $100 \mu \mathrm{g} / \mathrm{ml})$ and curcumin $(2.5-10 \mu \mathrm{M})$ for 3 days. Cell survival was determined by trypan blue dye exclusion.

and survival of U266 cells was determined by dye exclusion and MTT assays.

Trypan blue dye. Trypan blue was used to determine the U266 cell growth and survival after culturing with MGN-3 and curcumin for 3 days. Data in Figure 1 shows that treatment of U266 cells with curcumin alone $(2.5-10 \mu \mathrm{M})$ and MGN-3 alone $(50$ and $100 \mu \mathrm{g} / \mathrm{ml})$ resulted in a decrease in cell survival that followed a dose-dependent manner. On the other hand, the synergistic effect of MGN-3 plus curcumin caused a significant decrease in cell survival that also followed a dose-dependent manner that maximized ( $87 \%$ decrease in cell number) at a concentration of $100 \mu \mathrm{g} / \mathrm{ml} \mathrm{MGN}-3$ and $10 \mu \mathrm{M}$ curcumin.

MTT assay. Table 1 displays the percent U266 cell survival, determined via MTT assay, post-treatment with MGN-3 $(50,100 \mu \mathrm{g} / \mathrm{ml})$ and/or curcumin $(2.5-10 \mu \mathrm{M})$. Results show each agent suppresses tumor cell growth in a dose dependent manner. However, a combination of the two agents displays a synergistic effect on cell survival, in a dose-dependent manner $(\mathrm{p} \leq 0.0005)$.

Apoptosis. U266 cells were cultured with curcumin (2.5$10 \mu \mathrm{M})$, with or without MGN-3 $(50 \mu \mathrm{g} / \mathrm{ml})$. Apoptosis was determined by measuring hypodipolid DNA by FACScalibur. Data in Figure 2 shows that apoptosis induced by MGN-3 alone was similar to the background (10.0\%). Curcumin alone

Table 1. Cell viability (\%) via the MTT assay

\begin{tabular}{cccc}
\hline \multicolumn{3}{c}{ MGN-3 $(\boldsymbol{\mu g} / \mathbf{m l})$} \\
\hline Curcumin $(\boldsymbol{\mu M})$ & $\mathbf{0}$ & $\mathbf{5 0}$ & $\mathbf{1 0 0}$ \\
$\mathbf{0}$ & 100 & $88 \pm 9$ & $75 \pm 8$ \\
$\mathbf{2 . 5}$ & $86 \pm 9$ & $57 \pm 7$ & $51 \pm 6$ \\
$\mathbf{5}$ & $82 \pm 8$ & $54 \pm 6$ & $49 \pm 6$ \\
$\mathbf{1 0}$ & $76 \pm 6$ & $49 \pm 7$ & $43 \pm 5^{*}$ \\
\hline
\end{tabular}

U266 cells were treated with curcumin $(2.5-10 \mu \mathrm{M})$ in the presence or absence of MGN-3 (50-100 $\mu \mathrm{g} / \mathrm{ml}) .72$ hours post treatment MTT was added and cell survival was determined. Percentage cell viability $=(\mathrm{OD}$ of the experiment samples/OD of the control $) \times 100,\left({ }^{*} \mathrm{p} \leq 0.0005\right)$.

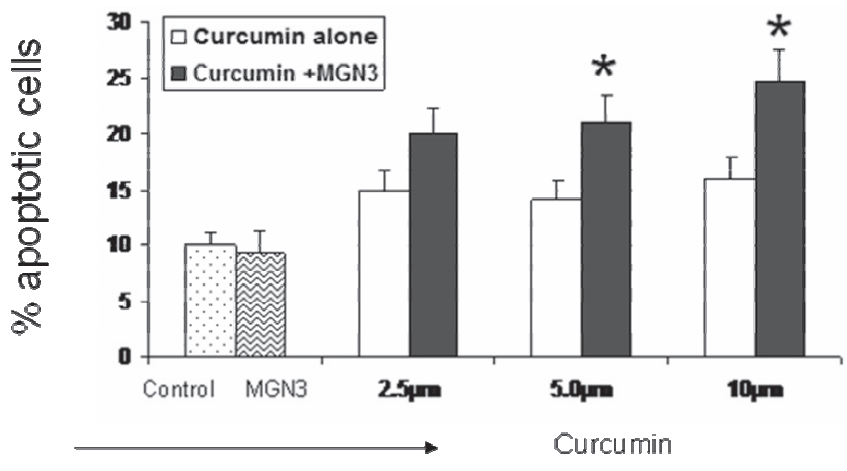

Figure 2. Apoptotic effect of MGN-3 and curcumin on U266 cells. U266 cells were cultured with MGN-3 $(50 \mu \mathrm{g} / \mathrm{ml})$ and curcumin $(2.5,5$ or $10 \mu \mathrm{M})$ for 3 days. Apoptosis was determined by measuring hypodipolid DNA by FACScalibur. ${ }^{*} \mathbf{p} \leq \mathbf{0 . 0 5}$

increased apoptosis in U266 cells. However, when MGN-3 was combined with curcumin, the levels of apoptosis were markedly increased to $20.0,22.0$, and $24.7 \%$ at curcumin concentrations of $2.5,5$, and $10 \mu \mathrm{M}$, representing a $200 \%$, $220 \%$, and $247 \%$ increase in cancer cell apoptosis, respectively $(\mathrm{p} \leq 0.05)$, as compared to the control untreated cells with either agent.

Cell cycle. The effects of MGN-3 and curcumin treatments on the cell cycle of U266 cells were examined. Data depicted in Figure 3 shows that treatment of U266 cells with either MGN-3 $(50 \mu \mathrm{g} / \mathrm{ml})$ alone or curcumin $(10 \mu \mathrm{M})$ alone caused no significant change in the percentages of cells in G0-G1, S phase and G2-M phase. While the treatment of U266 cells with MGN-3 plus curcumin caused a significant decrease in the G0 phase (53\%) from $36 \%$ to $17 \%(\mathrm{p} \leq 0.0005)$,a $16 \%$ decrease in the $S$ phase (from $15.5 \%$ to $13 \%$ ) and a $20 \%$ decrease in the G2-M phase (from $15 \%$ to $12 \%$ ) were also observed.

Pro and antiapoptotic molecules. The effect of MGN-3 and curcumin treatment on Bcl-2 and Bax expression was examined. Figure 4 shows that both MGN-3 and curcumin upregulated the proapoptotic molecule Bax. In addition, curcumin also down regulated the antiapoptotic molecule Bcl-2. However, the combination of MGN-3 plus curcumin resulted in a substantial decrease in $\mathrm{Bcl}-2$ expression. This resulted in alteration of $\mathrm{Bax}$ to $\mathrm{Bcl}-2$ ratio. The $\mathrm{Bax}$ to $\mathrm{Bcl} 2$ ratio in control, MGN-3 treated, curcumin treated and MGN-3 plus curcumin treated cells was $0.9,1.5,1.6$ and 2.5 , respectively.

\section{Discussion}

Multiple myeloma (MM) is an aggressive B-cell malignancy, and more than $90 \%$ of MM patients become chemoresistant. Therefore, several drugs have been tested in the search for a more effective treatment for MM, including PS341 (a proteosome inhibitor) and thalidomide (an inhibitor of TNF production) $[19,20]$. In this study, we selected two dietary agents, arabinoxylan rice bran $(\mathrm{MGN}-3)$ and 
curcumin, to explore their synergy in inducing apoptosis in human MM cells. Both agents have shown chemopreventive characteristics in animal models [5-9], and possess potent antioxidant potential [21-24]. The results of the current study showed that MGN-3 alone and curcumin alone have the ability to partially suppress the proliferation of U266 cells. Interestingly, a synergistic effect of both agents on U266 cell survival was noted. Combining both treatments resulted in a significant decrease in cell growth and an increase in cancer cell apoptosis.

Cell growth and apoptosis are independent, but linked, processes. In cancer cells, signaling pathways of both phenomena are deregulated. Bcl-2 family proteins are important regulators of cell survival and apoptosis. They are comprised of pro and anti apoptotic proteins. The members form heterodimers to inactivate each other. The upregulation of proapoptotic Bax expression and downregulation of antiapoptotic Bcl-2 expression have been demonstrated during both mitochondrial and death-receptor based apoptosis [25]. The mitochondrial pathway of apoptosis is dependent on the process of mitochondrial outer membrane permeabilization. Midochondrial based apoptosis can be stimulated by caspase dependent and caspase independent pathways and is regulated by members of Bcl-2 family [26-28]. Results of this study show that curcumin downregulated antiapoptotic Bcl-2 and MGN-3 upregulated proapoptotic Bax of U266 cells. In addition, combination of MGN-3 plus curcumin resulted in a substantial decrease in Bcl-2 expression. This would suggest that the observed synergistic effect of MGN-3 and curcumin may be partially due to modulation of signaling pathways mediated by Bcl-2 family members.

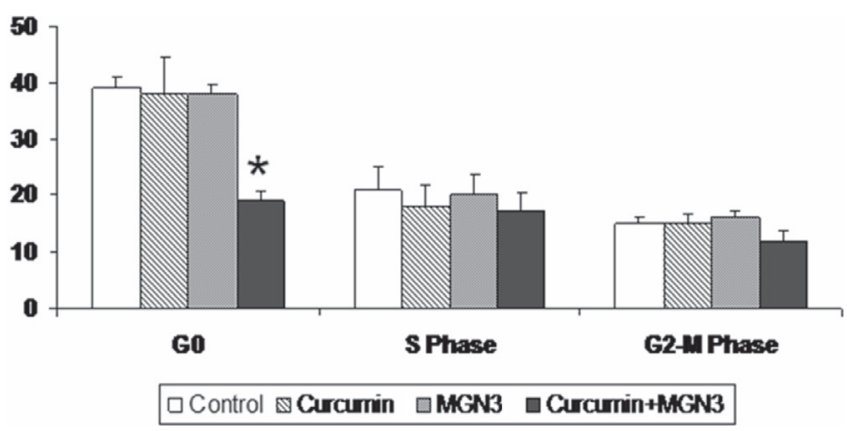

Figure 3. Cell cycle analysis of U266 cells post-treatment with MGN-3 and curcumin. U266 cells were cultured with MGN-3 $(50 \mu \mathrm{g} / \mathrm{ml})$ and curcumin $(10 \mu \mathrm{M})$ for 3 days. Cell cycle analysis was performed using flow cytometry. ${ }^{*} \mathrm{p} \leq \mathbf{0 . 0 0 0 5}$

In this study we showed that the combination of curcumin and MGN-3 decreased the proportion of U266 cells in G0G1, suggesting that these agents halt cell cycle progression and induce apoptosis. Several drugs and plant extracts have been shown to arrest cell growth at the G0-G1 phase and induce apoptosis in different cancer cell lines. These include: Gypenosides, a component of Gynostemma pentaphyllum Makino [29], Adiponectin [30], Terfenadine, a histamine H1 receptor antagonist [31] and Aucubin, an extract from the leaves of Aucuba japonica [32]. Curcumin has been reported to induce G1/S or G2/M arrest and apoptosis in other cancer cell lines [33] suggesting that the effect of curcumin is cancer cell type dependent.

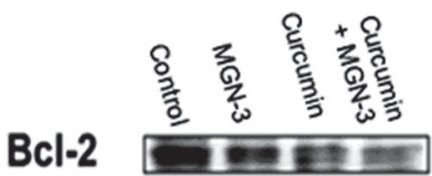

$\beta$-Actin

Actin normalized ratio

\begin{tabular}{|c|c|c|c|c|}
\hline & Control & MGN-3 & Curcumin & $\begin{array}{c}\text { Curcumin } \\
+ \text { MGN-3 }\end{array}$ \\
\hline Bcl-2 & 0.65 & 0.61 & 0.43 & 0.31 \\
\hline B-Actin & 1.00 & 1.00 & 1.00 & 1.00 \\
\hline
\end{tabular}

\section{Actin normalized ratio}

\begin{tabular}{|c|c|c|c|c|}
\hline & Control & MGN-3 & Curcumin & $\begin{array}{c}\text { Curcumin } \\
+\mathrm{MGN}-3\end{array}$ \\
\hline Bax & 0.72 & 1.31 & 1.26 & 0.56 \\
\hline$\beta$-Actin & 1.00 & 1.00 & 1.00 & 1.00 \\
\hline
\end{tabular}

Figure 4. Effect of MGN-3 and curcumin on the expression of Bax and Bcl-2. U266 cells were cultured with MGN-3 (50 $\mu \mathrm{g} / \mathrm{ml})$ and curcumin $(5 \mu \mathrm{M})$ for 1 day. Bax and Bcl-2 expression was visualized via Western blot. 
Nonspecific drug toxicity is a major problem in drug development. Discovery of a variety of therapeutic agents with less toxicity will lead to more effective therapies toward specific tumors. MGN-3 is an arabinoxylan extracted from rice bran [10] that has been shown to be a safe and nontoxic agent as manifested by the following: the LD50 (lethal dose, 50\%) of MGN-3 is greater than $36 \mathrm{~g} / \mathrm{kg}$; the Ames test for mutagenicity was negative; and the studies of subchronic toxicity, antigenicity and genotoxic testing in rats and guinea pig demonstrate that MGN-3 is nontoxic $[34,35]$. In addition, absence of toxicity in humans was reported using blood chemistry analysis [11]. Similarly, curcumin is widely used as a spice and coloring agent in several foods such as curry, mustard, bean cake, cassava paste, and potato chips as well as cosmetics and drugs. Earlier studies have shown that curcumin (diferuloylmethane) is pharmacologically safe and known to have very little or no toxicity in humans [36]. Phase 1 clinical trials showed that humans can tolerate up to $8 \mathrm{~g}$ curcumin per day when it is taken orally [37].

The immune modulatory effects by both MGN-3 and curcumin have been well documented. Earlier studies have shown that both agents are potent biological response modifiers that have the ability to boost different arms of the immune cells, such as NK cells, T cells, B cells, macrophages, dendritic cells and Treg cells [11-14, 38-41]. These characteristics, in addition to their ability to synergize in inducing apoptosis of cancer cells may add an additional weapon for fighting cancer. This may suggest a rationale for considering the combination of MGN-3 and curcumin in future studies for the treatment of multiple myeloma in clinical trials.

\section{References}

[1] HALLEK M, BERGSAGEL PL, ANDERSON KC. Multiple myeloma: increasing evidence for a multistep transformation process. Blood 1998; 91: 3-21.

[2] Diagnosis and management of multiple myeloma: UK myeloma forum. British Committee for Standards in Haematology. Br J Haematol 2001; 115: 522-540. doi:10.1046/ j.1365-2141.2001.03206.x

[3] Report: 1973-1989 Annual Cancer Statistics Review. Bethesda, MD: National Cancer Institute; 1992.

[4] FEINMAN R, KOURY J, THAMES M, BARLOGIE B, EPSTEIN J et al. Role of NF-kappaB in the rescue of multiple myeloma cells from glucocorticoid-induced apoptosis by bcl-2. Blood 1999; 93: 3044-3052.

[5] HUANG MT, SMART RC, WONG CQ, CONNEY AH. Inhibitory effect of curcumin, chlorogenic acid, caffeic acid and ferulic acid on tumor promotion in mouse skin by 12 O-tetradecanoylphorbol-13-acetate. Cancer Res 1988; 48: 5941-5946.

[6] HUANG MT, LYSZ T, FERRARO T, ABIDI TF, LASKIN JD et al. Inhibitory effects of curcumin in vivo lipoxygenase and cyclooxygenase activities in mouse epidermis. Cancer Res 1991; 51: 813-819.
[7] KUTTAN G, KUMAR KB, GURUVAYOORAPPAN C, KUTTAN R. Antitumor, anti-invasion, and antimetastatic effects of curcumin. Adv Exp Med Biol 2007; 595: 173-84. doi:10.1007/978-0-387-46401-5 6

[8] NOAMAN E, BADR EL-DIN N, BIBARS M, ABOU AA, GHONEUN M. Antioxidant potential by arabinoxylan rice bran, MGN-3/Biobran, represents a mechanism for its oncostatic effect against murine Solid Ehrlich Carcinoma. Cancer Letters 2008; 268: 348-359. doi:10.1016/j.canlet.2008.04.012

[9] BADR EL-DIN N, NOAMAN E, GHONEUM M. In vivo tumor inhibitory effects of nutritional rice bran supplement MGN3/biobran on Ehrlich Carcinoma-bearing mice. Nutrition and Cancer 2008; 60: 235-244. doi:10.1080/01635580701627285

[10] GHONEUM M. Anti-HIV activity in vitro of MGN-3, an activated arabinoxylan from rice bran. Biochem Bioph Res Comm 1998 a; 243: 25-29. doi:10.1006/bbrc.1997.8047

[11] GHONEUM M. Enhancement of human natural killer cell activity by modified arabinoxylan from rice bran (MGN-3). Int J Immunother XIV 1998 b; 2: 89-99.

[12] GHONEUM M, ABEDI S. Enhancement of natural killer cell activity of aged mice by modified arabinoxylan rice bran (MGN-3/Biobran). J Pharmacy Pharmacol 2004; 56: 1581-1588. doi:10.1211/0022357044922

[13] GHONEUM M, GOLLAPUDI S. Modified arabinoxylan rice bran (MGN-3/Biobran) sensitizes human T cell leukemia cells to death receptor (CD95)-induced apoptosis. Cancer Letters 2003; 20: 41-49. doi:10.1016/S0304-3835(03)00458-0

[14] GOLLAPUDI S and GHONEUM M. MGN-3/Biobran, modified arabinoxylan from rice bran, sensitizes human breast cancer cells to chemotherapeutic agent, daunorubicin. Cancer Detect Prev 2008; 32: 1-6. doi:10.1016/j.cdp.2008.02.006

[15] MOSSMAN T. Rapid colorimetric assay for cellular growth and survival: application to proliferation and cytotoxicity assays. J. Immunol. Methods 1983; 65: 55-63. doi:10.1016/ 0022-1759(83)90303-4

[16] ZHENG M, EKMEKCIOGLU S, WALCH ET, TANG CH, GRIMM EA. Inhibition of nuclear factor-kappaB and nitric oxide by curcumin induces G2/M cell cycle arrest and apoptosis in human melanoma cells. Melanoma Res 2004; 14: 165-171. doi:10.1097/01.cmr.0000129374.76399.19

[17] PARKA J, AYYAPPANE V, BAE EK. LEE C, KIM BS et al. Curcumin in combination with bortezomib synergistically induced apoptosis in human multiple myeloma U266 cells. Molecular Oncology 2008; 2: 317-326. doi:10.1016/ j.molonc.2008.09.006

[18] OLIVIER S, CLOSE P, CASTERMANS E, DE LEVAL L, TABRUYN S et al. Raloxifene-Induced Myeloma Cell Apoptosis: A Study of Nuclear Factor-kB Inhibition and Gene Expression Signature. Molecular Pharmacology 2006; 69: 1615-1623. doi:10.1124/mol.105.020479

[19] ADAMS J. Proteasome inhibition in cancer: Development of PS-341. Semin Oncol 2001; 28: 613-619. doi:10.1016/S00937754(01)90034-X

[20] BARLOGIE B, ZANGARI M, SPENCER T, FASSAS A, ANAISSIE E et al. Thalidomide in the management of multiple myeloma. Semin Hematol 2001; 38: 250-259. doi:10.1016/ $\underline{\text { S0037-1963(01)90017-4 }}$ 
[21] KUNCHANDY E, RAO MNA. Oxygen scavenging activity of curcumin. Int J Pharm 1990; 38: 239-240.

[22] SUBRAMANIAN M, SREEJAYAN, RAO MNA, DEVASAGAYAM TP, SINGH BB. Diminution of singlet oxygen induced DNA-damage by curcumin and related antioxidants. Mutat Res 1994; 311: 249-255. doi:10.1016/0027-5107(94)90183-X

[23] SREEJAYAN, RAO MNA. Curcuminoids as potent inhibitors of lipid peroxidation. J Pharm Pharmacol 1994; 46: 10131016.

[24] NOAMAN E, BADR RL-DIN N, BIBARS M, ABOU MOSSALLAM AA, GHONEUM M. Antioxidant potential by arabinoxylan rice bran, MGN-3/Biobran, represents a mechanism for its oncostatic effect against murine Solid Ehrlich carcinoma. Cancer Letters 2008; 268: 348-359. doi:10.1016/ j.canlet.2008.04.012

[25] OLATAVI ZN, MILLIMAN CL, KORSMEYER SJ: Bcl-2 heterodimerizes in vivo with a conserved homologue BAX that accelerates cell death. Cell 1994, 74:609-19.

[26] KUWANA T, NEWMEYER DD. Bcl-2-family proteins and the role of mitochondria in apoptosis. Curr Opin Cell Biol 2003; 15: 691-699. doi:10.1016/j.ceb.2003.10.004

[27] FESTJENS N, VAN GURP M, VAN LOO G, SAELENS X, VANDENABEELE P. Bcl-2 family members as sentinels of cellular integrity and role of mitochondrial intermembrane space proteins in apoptotic cell death. Acta Haematol 2004; 111: 7-27. doi:10.1159/000074483

[28] THOMADAKI H, SCORILAS A. Bcl-2 family of apoptosis-related genes: functions and clinical implications in cancer. Crit Rev Clin Lab Sci 2006; 43: 1-67. doi:10.1080/ $\underline{10408360500295626}$

[29] CHEN JC, LU KW, TSAI ML, HSU SC, KUO CL et al. Gypenosides induced G0/G1 arrest via CHk2 and apoptosis through endoplasmic reticulum stress and mitochondriadependent pathways in human tongue cancer SCC-4 cells. Oral Onc 2009; 45: 273-28. doi:10.1016/j.oraloncology.200 $\underline{8.05 .012}$

[30] KANG JH, LEE YY, YU BY, YANG BS, CHO KH et al. Adiponectin induces growth arrest and apoptosis of MDAMB-231 breast cancer cell. Archives of Pharm Res 2005; 28: 1263-1269. doi:10.1007/BF02978210

[31] LIU JD, WANG YJ, CHEN CH, YU CF, CHEN LC et al. Molecular Mechanisms of G0/G1 Cell-Cycle Arrest and Ap- optosis Induced by Terfenadine in Human Cancer Cells. Mol Carcinogen 2003; 37: 39-50. doi:10.1002/mc.10118

[32] HUNG JY, YANG JY, TSAI YM, HUANG HW, HUANG MS. Antiproliferative activity of aucubin is through cell cycle arrest and apoptosis in human non-small cell lung cancer A549 cells. Clin Exp Pharm Phys 2008; 31: 995-1001.

[33] SHISHODIA S, AMIN HM, LAI R, HUANG HW, HUANG MS. Curcumin (diferuloylmethane) inhibits constitutive NF-kappaB activation,induces G1/S arrest, suppresses proliferation, and inducesapoptosis in mantle cell lymphoma. Biochem Pharmacol. 2005, 70: 700-13. doi:10.1016/j.bcp.2005.04.043

[34] DAIWA PHARMACEUTICAL CO, LTD. BioBran rice bran arabinoxylan compound. http://www.daiwapharm.com/emd/ product.html

[35] TAZAWA, K. BioBran/MGN-3: Basic and clinical application to integrative medicine. Japan: Iyakushuppan Co. Publishers, 2003.

[36] BHARTI AC, DONATO N, SINGH, AGGARWAL BB. Curcumin (diferuloylmethane) down-regulates the constitutive activation of nuclear factor-kappa B and IkappaBalpha kinase in human multiple myeloma cells, leading to suppression of proliferation and induction of apoptosis. Blood 2003; 101: 1053-62. doi:10.1182/blood-2002-05-1320

[37] CHENG AL, LIN JK, HSU MM, SHEN TS, KO JY et al. Phase I chemoprevention clinical trial of curcumin [abstract]. Proc Am Soc Clin Oncol 1998; 17: 558.

[38] GHONEUM M and MATSUURA M. Augmentation of macrophage phagocytosis by modified arabinoxylan rice bran (MGN-3/biobran). Int J Immunopathol Pharmacol 2004; 17 : 283-292.

[39] CHOLUJOVA D, JAKUBIKOVA D, SEDLAK J. BioBran-augmented maturation of human monocyte-derived dendritic cells. Neoplasma 2009; 2: 89-95. doi:10.4149/neo $200902 \quad 89$

[40] LISSONI P, MISSINA G, BRIVIO F, FUMAGALLI L, VIGORE $\mathrm{L}$ et al. Modulation of the anticancer immunity by natural agents: inhibition of $\mathrm{T}$ regulatory lymphocyte generation by arabinoxylan in patients with locally limited or metastatic solid tumors. Cancer Ther 2008; 6: 1011-1016.

[41] JAGETIA GC, AGGARWAL BB. "Spicing up" of the immune system by curcumin. J Clin Immunol 2007; 27: 19-35. doi:10.1007/s10875-006-9066-7 